\title{
A Construção da Autonomia Política do Judiciário na América Latina: Um Estudo Comparado entre Argentina, Brasil, Chile, Colômbia e Venezuela
}

\author{
Fabiano Engelmann ${ }^{1}$ \\ Júlia Veiga Vieira Mâncio Bandeira ${ }^{1}$ \\ ${ }^{1}$ Universidade Federal do Rio Grande do Sul (UFRGS), Porto Alegre, RS, Brasil. E-mail: \\ fabengel@gmail.com
}

\section{INTRODUÇÃO}

s processos de redemocratização na América Latina trouxeram para a cena política, em diferentes graus, o Poder Judiciário. Mesmo compartilhando uma cultura jurídica comum, tributária do civillaw europeu (Friedman, Perdomo e Fix-Fierro, 2003), os países latinoamericanos apresentam diferentes trajetórias de interação de elites políticas com as judiciais que influenciam de forma determinante as condições de protagonismo político do Judiciário nas últimas décadas.

No quadro dessa problemática, temos por objetivo trazer elementos que contribuam para a compreensão, em larga escala, da dinâmica que circunda a construção das relações entre os Judiciários e o espaço político na América Latina a partir dos casos de Argentina, Brasil, Chile, Colômbia e Venezuela, com ênfase no período de 1990 a 2015. Para tanto, buscamos combinar a análise dos fatores da macro-história política com os padrões de recrutamento e autonomia das cúpulas judiciais em relação ao espaço político e governamental. Esses cinco países foram escolhidos devido a sua importância política e econômica na América do Sul e pelo fato de representarem casos exemplares de diferentes trajetórias na relação entre instituições judiciais e políticas que merecem análise mais detalhada.

O primeiro grande desafio é dar conta das diferentes configurações sócio-históricas e sociopolíticas dos países selecionados para o estudo

DADOS - Revista de Ciências Sociais, Rio de Janeiro, vol. 60, no-4, 2017, pp. 903 a 936. 
e seus distintos padrões de relação entre poder judicial e poder político. Embora em um primeiro momento a matriz de construção das instituições judiciais seja muito semelhante, tributária do modelo político-jurídico europeu, em um caso típico de "Estado importado" (Badie e Hermet, 1990), as diferenças entre as histórias e os padrões de interação das elites judiciais com as políticas são bastante nítidas nos casos estudados.

O artigo é dividido em duas partes, além desta introdução e das considerações finais. Na primeira parte trazemos elementos que julgamos fundamentais para o estudo do protagonismo político do Judiciário e de suas cúpulas e como essa problemática tem sido tratada na literatura latino-americana. Em uma segunda parte são expostos dados sobre os trajetos histórico-políticos dos Judiciários para cada país estudado, com ênfase nas Cortes Superiores nos últimos vinte anos.

\section{O ESTUDO DA LEGITIMIDADE POLÍTICA DAS CORTES JUDICIAIS NA AMÉRICA LATINA}

A emergência política do Poder Judiciário nos regimes latino-americanos tem sido estudada principalmente a partir da repercussão das decisões judiciais no campo político, em especial dos tribunais superiores. Os trabalhos representativos sobre a "judicialização da política" na América Latina ${ }^{1}$ apontam o incremento da relevância política das instituições judiciais, seja por meio de sua mobilização por movimentos sociais e por partidos políticos ou por meio de demandas individuais de cidadãos que reivindicam direitos sociais. Trabalhando em uma perspectiva analítica predominantemente neoinstitucionalista e ancorada no conteúdo de decisões judiciais, tais estudos deixam claro que os atores que controlam o espaço decisório da justiça nas democracias latino-americanas têm-se beneficiado de formatos constitucionais favoráveis à emergência do Poder Judicial como um ator político relevante. Os incentivos institucionais à presença do Judiciário na vida política têm destaque principalmente no patrocínio de causas oriundas de demandas por direitos de grupos sociais minoritários e do combate à corrupção política.

Mais preocupados com a construção da legitimidade política do Poder Judicial, outro conjunto de autores ${ }^{2}$ aborda mais especificamente os fatores que contribuem para o grau de sua autonomia nos países latinoamericanos e os diversos elementos institucionais e sociopolíticos que 
bloqueiam ou induzem a independência do poder decisório das elites judiciais. Nesses casos, os fatores histórico-políticos - expressos na trajetória mais longa de interação das elites judiciais com as elites políticas e no grau de estabilidade dos países - são determinantes para a apreensão das condicionantes da emergência política das instituições judiciais latino-americanas.

Também um volume significativo de trabalhos, cujo foco é a reforma do Judiciário na América Latina ${ }^{3}$, dedica-se a discutir a problemática da independência do Poder Judiciário a partir de indicadores mais gerais que têm por objetivo avaliar o desempenho judicial nos regimes democráticos. Para esses trabalhos, destacam-se como fatores relevantes para a independência judicial: 1 ) a presença de mecanismos que assegurem a independência jurisdicional à autonomia administrativa; 2) o respeito às decisões judiciais por parte dos Executivos e Legislativos; 3) a garantia dos direitos humanos; 4) a garantia de carreira para os juízes; e 5) a existência da possibilidade constitucional de revisão judicial. Tais fatores são apontados, por essa literatura, como essenciais para a afirmação de um modelo de instituições judiciais capaz de agir como garantia da legalidade, da segurança jurídica e, em termos políticos, como um poder contramajoritário.

Entretanto, quando se pretende analisar mais especificamente a relação entre as elites judiciais e as elites políticas para além da construção institucional, é importante pôr em pauta dois elementos. Primeiro, as condições de existência social e política que determinam a diferenciação de um segmento específico de agentes em relação a outros grupos que se destacam no espaço de poder. Segundo, os princípios que hierarquizam o espaço judicial que se pretende estudar. Nesse sentido, as características sociodemográficas predominantes e os percursos políticos e sociais aparecem como dimensões fundamentais a serem analisadas.

Instituições judiciais são espaços muito hierarquizados nos quais as cúpulas concentram poder decisório. Sendo assim, o posto de ministro em tribunais superiores configura uma das principais posições de elite. Nesse sentido, cresce a importância de se estudar o perfil dos agentes posicionados nas cúpulas das Cortes Constitucionais que, além da interpretação final da Constituição, podem acumular também jurisdição sobre outros temas com repercussão no espaço político. 
O que caracteriza a autonomia das cúpulas judiciais em determinado contexto, para além de suas garantias legais, é a existência de um conjunto de agentes que exerce um poder calcado no predomínio da expertise jurídica com relativa autonomia em relação a outras espécies de poder político e burocrático. As condições dessa autonomia são garantidas por "efeitos de instituição" presentes nos diferentes ordenamentos constitucionais e em regras específicas sobre a atuação desses agentes. Também tem um papel importante a legitimidade simbólica ancorada na crença generalizada sobre a importância da autonomia do Poder Judiciário que se cristaliza nos países latino-americanos - em diferentes ritmos - nos últimos anos (ver Burgos, 2003). Finalmente, as estratégias dos juristas para exercer o poder - e garantir seu monopólio de "dizer o direito" - contribuem para a construção social da especificidade do que se pode denominar o campo jurídico, no sentido a ele atribuído por Pierre Bourdieu (1986).

Para além da problemática da hierarquização interna do Judiciário (ver Engelmann, 2012), parte significativa dos estudos abordando as elites judiciais tem por objeto a construção da autonomia dos profissionais do direito frente a outras espécies de elites políticas e burocráticas. Assim, o investimento em um ethos de separação das magistraturas em relação ao espaço político por meio do predomínio da ideia de neutralidade das decisões judiciais e da vedação institucional da participação na vida político-partidária historicamente fez parte da construção de um Poder Judiciário autônomo nos países europeus (ver Bancaud, 1993; Ferreira, 2001), assim como no caso brasileiro (Koerner, 1998). A comparação de trajetórias políticas, acadêmicas e profissionais dos ocupantes dos cargos mais altos das Cortes indica, nesse sentido, padrões de interação das elites judiciais com as políticas. Quando cotejadas com a trajetória macro-histórica da relação entre justiça e política nos diferentes países, elas permitem inferências relevantes sobre o grau de autonomia do Poder Judicial.

\section{OS ESTUDOS DE CASO}

Os casos abordados neste artigo são apresentados em duas etapas. Primeiro, expomos um breve panorama histórico-político da interação das elites judiciais e do espaço político do país. Em um segundo momento, analisamos os dados coletados sobre os perfis e os trajetos dos componentes de sua Corte dos últimos 25 anos. Foram mapeados 286 ministros das Cortes Superiores de Argentina, Brasil, Chile, Colômbia 
e Venezuela atuando entre 1990 e 2015, sobre os quais obtivemos informações biográficas que foram agregadas, por país, a partir dos seguintes parâmetros: 1) dados relacionados à presença dos ministros nas Cortes (número de ministros, data de ingresso mais antiga, número de renúncias, número de destituições); 2) dados sobre o perfil dos ministros (local de nascimento, titulação acadêmica, universidade onde se graduou e livros publicados); e 3) dados sobre o trajeto dos ministros (percurso profissional prévio, atividades acadêmicas, atividades políticas, ocupação de cargos em direções de tribunais, ocupação de cargos em direções de associações, livros publicados e inserção internacional).

Para a coleta de informações foram utilizados, predominantemente, os sites das respectivas Cortes. No entanto, em quase todos os casos as informações contidas nesses sites se mostraram insuficientes, de modo que foi necessário recorrer a fontes diversas, em especial aos principais jornais dos países, para suprir lacunas. Na Argentina, no Chile e na Colômbia, por exemplo, os sites institucionais das Cortes expõem apenas os currículos sintetizados dos magistrados que estão atuando. No caso brasileiro, a página web institucional do Supremo Tribunal Federal apresenta o currículo de todos os ministros de forma bastante completa. O caso da Venezuela foi o mais complicado, pois o site do Tribunal Supremo de Justicia publica apenas alguns currículos de seus 32 magistrados em atuação e de poucos ex-magistrados. Também é importante observar a disparidade entre o número de ministros mapeados por país que oscila muito devido ao fato de o número de componentes e a rotatividade das Cortes variarem bastante.

\section{Cúpulas Judiciais Condicionadas pelo Jogo Político: O Caso da Argentina}

A estrutura judicial argentina formada no século XIX foi amplamente influenciada pela organização judicial norte-americana. A influência estadunidense alcançou também as decisões da Corte Suprema de Justicia de La Nación Argentina que sustentava uma concepção liberal inflexível atuando como defensora da propriedade individual (Del Río, $2012)^{4}$. A estabilidade e o crescimento econômico do país entre 1860 e 1930, construídos em paralelo a essa exportação de ideias e instituições (Dezalay e Garth, 2002), possibilitaram à Corte manter relativa independência e autonomia jurisdicional. Conformou-se, assim, como 
uma instituição respeitada, cujas sentenças demarcaram seus poderes no jogo político e institucional do país (Negretto e Ungar, 1997).

Além disso, a Corte argentina foi capaz de acompanhar as transformações sociais pelas quais o país passou em meados da década de 1910 quando a república oligárquica foi substituída por uma democracia de massas - abandonando, assim, a ideologia liberal para se orientar a favor de uma maior intervenção do Estado na economia (Del Rio, 2012). Talvez isso tenha sido um reflexo de seu modelo de recrutamento ${ }^{5}$, contudo, em nenhum momento ela precisou ser controlada, nem guiada politicamente (Helmke, 2005).

A partir de 1930, quando ocorre o primeiro colapso institucional do país, esse quadro de estabilidade e independência do Judiciário é abalado. O período entre 1930 e 1983 foi caracterizado por tensões institucionais e pela "legalidade de fato". O próprio Judiciário foi o primeiro a reconhecer a legitimidade dos distintos golpes empreendidos em 1930, 1943, 1955, 1962, 1966 e 1976 por meio de acordadas que os validaram juridicamente (Sabsay, 2004; Acunã e Alonso, 2003). A Corte Suprema passou a ser diretamente atingida a partir de 1947, quando o governo eleito de Juan Perón (1946-1952) destituiu quatro dos cinco ministros que a compunham por terem legitimado o golpe de 1930. A destituição dos ministros durante o governo Perón contribuiu para a construção de um padrão que atrelou fortemente o recrutamento dos ministros aos governos. Desde então, as trocas de governo acarretaram a modificação integral na composição da Corte $^{6}$. Esses cinquenta anos da história argentina - como pontuam Yves Dezalay e Bryant Garth (2002) - foram marcados pela fragilidade do direito e das instituições estatais. Consolidaram um padrão de atuação e composição do Judiciário ancorado na patronagem, no clientelismo e no poder militar que relegou a um segundo plano a legitimação da Corte a partir de sua autonomia política e jurisdicional.

Mesmo com a transição democrática marcada pela eleição de Raúl Alfonsín em 1983, o Judiciário seguiu sendo um Poder vulnerável ao Executivo. Um exemplo disso foi a composição da Corte no processo de redemocratização. Apesar do consenso entre as forças políticas sobre a importância de sua autonomia e mesmo da pressão dos militares para mantê-la "intacta", Alfonsín removeu todos os juízes da Corte, pois entendeu que eles careciam de legitimidade, e indicou seus suces- 
sores de forma proporcional às forças partidárias ${ }^{7}$ (Novaro e Palermo, 2007).

Durante o governo de Carlos Menem (1989-1999), o aparelhamento da Corte também foi evidente. Em seus primeiros meses de mandato, ele ampliou sua composição de cinco para nove ministros utilizando como justificativa a ineficiência do Tribunal. A Corte se posicionou contra a reforma, o que levou dois juízes a renunciarem quando a expansão foi aprovada pelo Congresso. Todos os seis ministros nomeados por esse episódio - conhecido como "maioria automática" ${ }^{8}$ - tinham estreitos laços com o Presidente. Apesar dessas medidas, foi durante o governo Menem que ocorreu a redação da reforma constitucional de 1994. A modificação retirou o poder do Executivo sobre o ingresso na carreira judicial implementando o concurso público para os tribunais inferiores. Já para o recrutamento da Corte Suprema foi expandida a maioria necessária para a aprovação das nomeações no Senado (Skaar, 2003).

O governo de Néstor Kirchner (2003-2007) também entrou em conflito com a Corte ao propor o impeachment dos quatro ministros remanescentes da "maioria automática". Frente a isso, três renunciaram e um foi efetivamente destituído pelo Congresso. Para completar as novas vacâncias, em vez de realizar nomeações políticas, foram introduzidos, em 2003, mecanismos de restrição da discricionariedade do Presidente. A partir de então, a inclusão de novos integrantes da Corte passou a ter de refletir as diversidades de gênero, especialidades e procedência regional do país. Também visando deixar o processo "mais transparente e participativo", os candidatos à Corte passaram a ser divulgados e houve a abertura de uma instância de consulta pública (Herrero, 2012).

Laura Menajovsky (2015) sublinha que essas mudanças moldaram a Corte como um ator político relevante e iniciaram um processo de reconfiguração de sua autoridade e legitimidade, que haviam se tornado ínfimas no governo Menem. Lucas Martín (2011) aponta que, desde então, a Corte adquiriu maior visibilidade pública e os magistrados vêm incidindo de maneira mais direta na imagem do Judiciário, elaborando um discurso público da Justiça a respeito de si mesma - o que é uma novidade no cenário do país9.

Para a análise dos dados da Argentina foram mapeados 18 magistrados da Corte Suprema de Justicia de la Nación entre 1990 e 2014, tendo 
o magistrado mais antigo ingressado em $1983^{10}$. O número relativamente pequeno de autoridades judiciárias deve-se ao fato de que a Corte argentina é a que possui menor quantidade de componentes entre os países estudados. No intervalo analisado, o número de ministros flutuou entre nove sob o governo de Menem, sete sob Néstor Kirchner e cinco sob Cristina Kirchner. $\mathrm{O}$ dado relacionado à presença dos ministros na Corte que mais chama a atenção diz respeito ao número de renúncias e destituições ao longo do período.

No total foram nove renúncias e duas destituições por "mal desempenho de funções". É possível separar os 11 casos em dois períodos. O primeiro ocorre entre 1993 e 1995 quando Mariano Cavagna Martínez, Rodolfo Barra e Ricardo Levene renunciaram em cumprimento a uma das condições para o Pacto de Olivos ${ }^{11}$, que teve por consequência a substituição de metade da "maioria automática". O segundo período vai de 2003 a 2005, quando Julio Nazareno, Guillermo Fernando López e Adolfo Roberto Vásquez renunciaram para evitar sua destituição pelo Senado; Augusto César Belluscio renunciou para se aposentar e Eduardo Moliné O'Connor e Antonio Boggiano foram destituídos pelo Senado como consequência da disputa travada entre o presidente Néstor Kirchner e os juízes remanescentes da "maioria automática". As outras duas renúncias não se encaixam no padrão. A instabilidade dos ministros evidenciada no volume de renúncias pode ser relacionada, portanto, às históricas ingerências dos governos na Corte com a indicação de partidários e a pressão para saída de componentes identificados com governos anteriores.

No concernente ao perfil dos ministros, destaca-se o fato de que a maioria possui curso de doutorado na Universidad de Buenos Aires ou em outras universidades argentinas, evidenciando uma formação endógena, sem a realização de estudos no exterior. O peso daquela instituição e o fato de mais de a metade dos ministros ter origem na capital indicam relativa concentração territorial na Corte. Essa característica se acentua ao juntarmos os juízes originários da capital com aqueles das províncias da região central (Salta, Córdoba e Buenos Aires).

Quanto à inserção internacional, nos poucos casos em que esteve presente, ocorreu na forma de curtas estadias relacionadas à docência universitária e realização de cursos de pós-graduação. Dos sete ministros com algum tipo de percurso internacional, quatro foram nomeados pelo presidente Kirchner apontando uma tendência mais recente. A 
participação em associações, por outro lado, mostra-se uma variável consolidada: 13 ministros apresentaram participação ativa em mais de uma associação. Isso também é um reflexo da forma de interação do campo jurídico no país, que se mostra amplamente engajado em associações e fundações. O perfil desse associativismo é tanto corporativo quanto relacionado a diversos temas jurídicos e culturais. Os cinco juízes que não apresentam indícios de tal participação foram nomeados por meio de manobras do presidente Menem.

Sobre as atividades profissionais prévias dos ministros, a maioria é oriunda de profissões jurídicas. Seis provêm da magistratura, cinco do exercício da advocacia e um da procuradoria. Assim, apenas três ministros podem ser caracterizados como "típicos políticos", no sentido de terem passado por cargos eletivos. No entanto, quatro juízes oriundos da advocacia exerceram também cargos de confiança no Executivo dos diferentes níveis de governo. Não obtivemos informação acerca da passagem dos ministros por cargos de direção em tribunais. Também mais da metade dos magistrados que passaram pela corte, 14 casos, exerceu atividades docentes e possui publicações de livros na área do direito e da literatura.

\section{Autonomia e Ambivalência em Relação ao Espaço Político: O Caso Brasileiro}

No caso brasileiro, o Poder Judiciário esteve historicamente vinculado ao poder político sendo diversas vezes exercido pelas mesmas pessoas (ver Engelmann, 2006; Barbosa, 2003). Os estudos de Andrei Koerner (1998) e Luciano Da Ros (2012) demonstram tal realidade ao analisar as modalidades de vínculos dos magistrados e ministros da Corte Suprema brasileira na I República. Mais da metade dos membros indicados para o Supremo eram filiados a partidos políticos. Tal proporção caiu no governo Getúlio Vargas (1930-1945) com a introdução de reformas inspiradas no modelo corporativista, levando à priorização de nomeações sem vínculos político-partidários. Porém, no período democrático de 1946 a 1963, a proporção de ministros do Supremo recrutados junto a partidos políticos voltou a subir, decrescendo na ditadura militar e no período democrático pós-1988. Da Ros (2012) e Fabiano Engelmann (2012) mostram que a tendência a um recrutamento que enfatizasse a expertise e o recrutamento endógeno ao espaço jurídico cresceu no período democrático. Sendo assim, o grande desafio é 
verificar quais espécies de recursos políticos específicos ao campo jurídico são mobilizadas pelos juristas para a ascensão à Corte.

Apesar de o governo Vargas ter restringido a independência judicial, foi nesse período que teve início a profissionalização do Judiciário com a institucionalização do concurso público para as magistraturas de primeira instância e a preferência pela nomeação de ministros do Supremo Tribunal Federal (STF) menos conectados com a vida políticopartidária do país. Com o advento da ditadura militar (1964-1986), o Judiciário teve sua independência atingida novamente. O conflito com o governo ditatorial iniciou-se ainda em 1964, quando o Tribunal passou a outorgar diversos habeas corpus contrários aos interesses do governo, defendendo em suas sentenças direitos individuais como a liberdade de expressão. Como resposta à postura do Tribunal, o governo lançou o Ato Institucional no2 (AI-2) que aumentou de 11 para 16 o número de ministros do STF. $\mathrm{O}$ ato também estipulou que civis fossem julgados pela Justiça Militar - sob a justificativa da segurança nacional - privando a Justiça de se manifestar sobre os atos institucionais. Já com o AI-5, promulgado em 1968, as prerrogativas judiciais foram ainda mais restringidas e o STF foi diretamente atingido com a cassação de três de seus ministros. Na época, dois ministros renunciaram em solidariedade aos colegas. Com isso, os militares restabeleceram a composição de 11 ministros no STF. A última alteração em sua composição foi a renúncia de Adaucto Lúcio Costa, em 1971, por ser o único no Tribunal contrário à lei da censura prévia. A situação do Judiciário só iria se estabilizar depois de 1978, quando os atos institucionais foram revogados, o que contribuiu para o início da recuperação da autonomia jurisdicional e política de suas instituições.

Com o fim do regime militar e o advento da Constituição de 1988, o Judiciário brasileiro conquistou grande independência política e adquiriu capacidade de enfrentar os Poderes Executivo e Legislativo e arbitrar disputas entre governo e oposição. Esse ativismo político evidencia elementos que diferenciam o Judiciário brasileiro dos casos da Colômbia e do Chile, que conservam sua independência enquanto Poder de Estado, mas não assumem protagonismo político significativo.

A pesquisa sobre os perfis dos ministros do Supremo Tribunal Federal entre 1990 e 2015 indica padrões de carreira profissional em que o domínio da expertise jurídica e a detenção de capital político aparecem imbricados (ver Engelmann, 2012 e Almeida, 2010). No período estudado 
não ocorreram destituições ou renúncias por pressão política, indicando que a Corte brasileira, no período pós-redemocratização, adquire um padrão de estabilidade e autonomia.

A distribuição da origem geográfica dos ministros é diversificada predominando os oriundos da região Sudeste, a mais populosa do país. A maioria dos ministros da Corte sobre os quais obtivemos informações acerca do local de graduação, 15 casos, formou-se nas universidades públicas de maior prestígio do sul e do sudeste do país, regiões economicamente mais desenvolvidas e populosas.

A atividade acadêmica também está presente na trajetória da maioria dos atores analisados: 23 casos. Nota-se que uma minoria de ministros mais antigos na Corte, e com maior inserção no âmbito da política partidária, não exerceu atividade de professor universitário. Todos os mapeados mencionam em seus currículos a publicação de algum artigo na área jurídica e 25 possuem publicações de livros na área do direito. Mais da metade, 17 casos, apresentou algum tipo de inserção internacional, cinco deles na forma de cursos de pós-graduação. Quanto à atividade profissional prévia, a grande maioria, 21 casos, provém de carreiras da área jurídica: magistratura, Ministério Público e Procuradoria. Uma minoria dos ministros (quatro casos) deteve cargo eletivo, e dez ocuparam cargos em governo, como secretário, ministro ou assessor. Assim, a combinação desses dois tipos de trajetória com intersecção na política apresenta no Brasil seu maior índice, abrangendo $48 \%$ dos ministros. Dos 11 ministros atuando no primeiro semestre de 2016, nenhum havia passado por cargo eletivo ou ministério. Nove deles ocuparam cargos de direção em tribunais antes de ingressarem na Corte. Também é significativa a passagem por diversas espécies de associações e, em seis casos, em postos de direção da Ordem dos Advogados brasileira.

\section{Forte Hierarquização e Autonomia Judicial: O Caso da Chile}

A estrutura organizacional do Judiciário chileno conserva as características essenciais do sistema judicial monárquico estabelecido no período colonial, de modo que em mais de 200 anos de República, em comparação com outros casos, sua evolução institucional foi bastante lenta $^{12}$ (Lizana, 2001). Desde sua instituição em 1823, a Corte Suprema de Justicia de Chile acumulou a superintendência diretiva, correcional, econômica e moral sobre todos os tribunais e juizados da nação 
com funções jurisdicionais, estabelecendo um grande poder dentro da própria estrutura do Judiciário (Monardes, 2005). Já no século XIX, por exemplo, a Corte mantinha faculdades disciplinares e participação na escolha de seus magistrados. Na época, o presidente selecionava seus juízes por meio de uma lista elaborada pelo Conselho de Estado e pela própria instituição. Entretanto, mesmo com este perfil de estrutura institucional, o Poder Judicial mantinha um papel político secundário.

Lisa Hilbink (2007) pontua que, com o advento do parlamentarismo em 1891, os partidos oligárquicos realizaram um grande expurgo no Judiciário, substituindo cerca de $80 \%$ dos magistrados por juízes leais aos partidos. Esse episódio não foi alvo de grande oposição, nem pela ideologia positivista, que atribuía um papel passivo e subordinado aos juízes, tampouco pelos laços sociais ${ }^{13}$ e ideológicos compartilhados pelas cúpulas judicial e política (Cumplido e Fruhling, 1980). Além disso, os juízes de todas as instâncias passaram a ser escolhidos mais por suas lealdades partidárias do que por seus méritos profissionais e a Suprema Corte já não tinha mais participação nas nomeações.

A Constituição de 1925 foi o marco que definiu, de fato, a independência e a autonomização do Judiciário chileno, consolidando o sistema de recrutamento por cooptação indireta ${ }^{14}$. Nesse sistema, a Corte Suprema definia uma lista de cinco pessoas para vagas em seus próprios quadros e uma lista tripla para vagas nas Cortes de Apelação (segunda instância). Já para o ingresso na carreira judicial, no nível de juiz distrital, a Corte de Apelação formulava uma lista com três pessoas. Todas as listas eram apresentadas ao Executivo, que nomeava os magistrados escolhidos. Com esse modelo, o papel da hierarquia tornou-se o eixo central da organização judicial. Contudo, conforme argumenta Hugo Fruhling (1980), o contexto que permeou a reorganização judicial foi marcado pelo desmembramento do Estado oligárquico e pela construção de novas e conflitivas relações políticas. Esse cenário contribuiu para deixar o Judiciário anacrônico, sem renovação ideológica e distante das mudanças da realidade sociopolítica do país.

Por conta desse distanciamento, é com surpresa que as elites políticas vivenciaram o protagonismo judicial durante o governo de Salvador Allende (1970-1973). Uma das linhas interpretativas dos embates entre os Poderes na época pontua que isso ocorreu pelo fato de o programa de Allende contrapor-se radicalmente ao ideal institucional desejado pelo Judiciário (Fruhling, 1980; Echeverría, 2011), em especial por ameaçar a autonomia corporativa alcançada por aquele Poder e pres- 
supor um papel politicamente ativo do juiz que passaria a ser um agente de transformação social. Essa visão tensionava o modelo de imparcialidade e distanciamento do Judiciário que conformava a tradição chilena. Foi também nesse período que, pela primeira vez em sua história, a Corte utilizou sistematicamente seu poder disciplinar e a faculdade de destituir juízes por "mau comportamento". Assim, todos os juízes que mostravam apoio às ideias de Allende eram expulsos da estrutura judicial (Hilbink, 2007).

Depois do golpe militar de 1973, como mostra Hilbink (2003; 2007; 2008), a junta militar assegurou o funcionamento normal do Judiciário a fim de mostrar o comprometimento de Augusto Pinochet com a independência judicial. Portanto, frente ao projeto autoritário, os tribunais reagiram de forma muito diversa da oposição realizada no governo Allende, sustentando a estrutura institucional criada pelo regime ao ancorar-se no discurso da independência judicial. Assim como no período de Allende, a Corte Suprema utilizou-se de suas prerrogativas disciplinares, mas para afastar ou censurar aqueles juízes que emitiam opinião pública em defesa de princípios liberais e dos direitos humanos ou que davam continuidade a julgamentos contrários ao Executivo. Como relatado por Hilbink (2008), no início do período, em 1974, a Suprema Corte demitiu ou forçou a aposentadoria de 15\% do quadro de magistrados.

Com a redemocratização, a reforma judicial foi uma peça central nos programas de governo. O Judiciário opôs-se, porém, às tentativas de reformas, bloqueando diversos projetos de lei que almejavam democratizar as instituições estatais (Skaar, 2003). De todos os projetos apresentados durante a década de 1990, poucos foram efetivamente aprovados. Entre as principais mudanças destaca-se a criação da Academia Judicial, que passou a gerir o ingresso na magistratura. O concurso público foi instituído, prevendo a incorporação de cinco advogados não pertencentes ao Judiciário e selecionados a partir de concurso público de antecedentes. A Corte teve, dessa forma, sua composição ampliada de 17 para 21 magistrados. A cooptação indireta, a profissionalização apolítica dos juízes e o papel centralizador da Corte Suprema possibilitaram ao sistema judicial chileno construir-se historicamente com maior autonomia em relação aos poderes políticos. Entretanto, esse modelo propiciou, também, o fechamento do poder em si mesmo, o que levou a fenômenos complexos como a sua excessiva hierarquização (ver Sousa, 2007 e Squella, 2007). 
Apesar de as informações sobre o perfil da Corte nos últimos anos serem de fácil acesso, à medida que nos aproximamos dos juízes indicados pela ditadura, elas vão tornando-se mais escassas. Além disso, visto que os magistrados da Corte Suprema são juízes de carreira, no sentido mais estrito da noção, as informações curriculares se limitam a descrever a ascensão na hierarquia. No período analisado, 67 ministros passaram pela Corte, número alto, visto que ela é composta de 21 juízes com mandato vitalício. Desse universo, não foram obtidas informações sobre 15 magistrados, nove dos quais indicados por Pinochet, três por Patricio Aylwin e três por Eduardo Frei Ruiz-Tagle. Entre os dados reunidos, destaca-se a baixa inserção internacional, a carreira altamente estruturada - isto é, os magistrados da Corte passaram por todas as instâncias e cargos do Judiciário antes de se tornarem ministros - e a baixa participação associativa. Isso indica que o recrutamento valoriza fatores endógenos, de modo que, para se tornar ministro, o juiz não necessita mobilizar recursos de legitimação externos ao Poder Judiciário. Além disso, as associações não têm muita importância, pois as cúpulas judiciais esvaziam sua capacidade de se afirmarem como porta-vozes de reivindicações políticas e corporativas dos juízes.

Pelos números obtidos, podemos observar que não há muitos magistrados com formação de pós-graduação, pois a inserção na carreira judicial costuma ocorrer logo após a graduação e não há incentivos para uma maior formação acadêmica. Sobre os estudos universitários de graduação, predomina a formação na universidade mais importante do país, a Universidad de Chile, por onde passou quase metade dos integrantes. Para os 52 casos trabalhados, a maioria, 33, atuou como professor universitário. Além disso, é possível perceber uma tendência crescente de ministros com passagem pela docência na Academia Judicial, com aumento da frequência a partir dos anos 2000. Desde então, metade dos juízes nomeados, 15, haviam sido professores da Academia. Por último, é interessante notar que o Chile foi o único país em que não houve ministro com passagem por cargos políticos e foi o último país a incorporar uma mulher na Corte Suprema com a nomeação de María Antonia Morales em 2001.

\section{Cooptação e Poder Concentrado nas Cúpulas: O Caso da Colômbia}

A instabilidade político-institucional foi por muito tempo um fator constante na história colombiana. Até meados do século XX, tal fenômeno esteve associado à disputa entre liberais e conservadores pelo poder estatal. A partir da década de 1960, contudo, a instabilidade 
passou a estar relacionada ao crescimento de grupos guerrilheiros e paramilitares. Esses elementos impactaram o sistema judicial como um todo e a Corte Suprema de Justicia de Colômbia em especial. Devido à intensa polarização política entre os partidos Liberal e Conservador, que frequentemente desembocava em conflito bélico, houve diversas tentativas de consolidar a Corte Suprema como uma instituição capaz de "ordenar" o país durante o primeiro centenário da República colombiana (Sarria, 2008; 2013). Contudo, os momentos de maior centralidade da Corte eram acompanhados por uma grande ingerência política. Por exemplo, o sistema de recrutamento dos magistrados oscilava repetitivamente entre o modelo semelhante ao chileno, de cooptação, quando o Judiciário tinha papel periférico no sistema político, e a eleição pelo Congresso ou indicação pelo Executivo, momentos em que se requeria maior protagonismo político do Judiciário. Esse quadro combinado com a herança espanhola conformou um Judiciário extremamente passivo e formalístico (Nagle, 1995).

Apesar da polarização, instabilidade e subordinação do Judiciário, a destituição de juízes não era uma realidade no país. Ao contrário, os mandatos dos magistrados foram respeitados mesmo na transição da hegemonia conservadora (1910-1930) à liberal (1930-1946) e na ditadura do General Gustavo Rojas Pinilla (1953-1957) ${ }^{15}$. Isso não significa que a independência dos juízes tenha sido observada, visto que o recrutamento era organizado de forma a espelhar, na Corte, a proporção da representação adquirida pelos partidos Conservador e Liberal no Legislativo (Bushnell, 1993).

Foi em 1957 que a Corte Suprema conquistou maior independência. Naquele ano, uma Junta Militar tomou o poder para ordenar a transição da ditadura de Rojas para um novo governo constitucional, o que desembocaria na formação da Frente Nacional ${ }^{16}$. A instauração da Frente por meio de uma reforma constitucional facultou ao Judiciário sua independência orgânica. Com a justificativa de distanciar a politização das altas cortes, a Junta Militar incluiu no referendo o mecanismo de cooptação direta, abrangendo todas as instâncias judiciais (Samper, 2012). No mesmo sentido, o mandato de cinco anos para os juízes foi substituído pela vitaliciedade. Todavia, tais mecanismos não evitaram que as Cortes fossem divididas entre os partidos. Assim, nos termos de Sebastian Galvis (2009), as quotas dos partidos foram mantidas informalmente durante a Frente Nacional. Mesmo não obedecendo a critérios abertamente partidários, as divisões obedeceram a afini- 
dades ideológicas, criando uma modalidade própria de clientelismo (Guevara, 2011).

Apesar da independência que havia adquirido, o Poder Judicial tinha um papel marginal no arranjo da Frente, pois o estado de sítio e o fortalecimento dos tribunais militare ${ }^{17}$ tinham se tornado práticas comuns (Villegas, 2009). O Judiciário, no entanto, não agiu contra a usurpação de suas prerrogativas, dando legitimidade às declarações de estado de sítio e à extensão da jurisdição militar. As poucas vezes em que a Corte Suprema se impôs no cenário político ocorreram nas tentativas de reformar o Judiciário (Samper, 2012; Sarria, 2008; Moreno, 2004).

O desmantelamento do aparato da Frente Nacional na década de 1980 ocorreu concomitantemente à expansão da violência no país e ao engajamento do Judiciário. Nesse período, a Corte Suprema tornou-se mais ativa, virando alvo de críticas da elite política. A raiz dessa mudança de posição é a penetração na judicatura da violência que abatia o país ${ }^{18}$. Conforme Gabriel Nemoga (1995), a partir de então, a Corte passou a representar um obstáculo ao exercício do poder, fazendo com que representantes governamentais alegassem que a Colômbia estava vivendo um "governo dos juízes". Apesar das vitórias que a Corte conseguiu ostentar durante os anos 1980, com a Constituição de $1991^{19}$, o Executivo conseguiu impor diversas mudanças ao Judiciário, como: 1) a instituição da carreira judicial e dos concursos públicos para os tribunais de primeira instância; 2) a criação do Conselho Superior da Judicatura $^{20}$, que passou a participar da nomeação dos magistrados da Corte Suprema de Justicia e do Consejo de Estado ao elaborar as listas pelas quais deveriam ser escolhidos os novos ministros; 3 ) a substituição da vitaliciedade dos ministros da Suprema Corte pelo mandato de oito anos; e 4) a transferência da competência de revisão constitucional da Corte para a Corte Constitucional, que tem seus ministros nomeados pelo Senado por meio de listas organizadas pelo Presidente, pela Corte Suprema de Justicia e pelo Consejo de Estado ${ }^{21}$.

No período recente, apesar de destituída do poder de revisão constitucional, a Corte tem mantido algum protagonismo, principalmente pelos processos de desmobilização dos paramilitares e das guerrilhas. No entanto, sua atividade nem sempre é respeitada. O maior exemplo disso foi o embate constante com o presidente Álvaro Uribe (2002-2010). O ápice do conflito entre os dois Poderes se deu no escândalo das chuzadas, quando se descobriu que o presidente havia gram- 
peado ilegalmente os telefones dos magistrados da Corte que atuavam na desmobilização dos paramilitares, além de outros personagens da vida política nacional.

Partindo para a análise dos dados dos ministros da Corte Suprema é importante ressaltar que as informações apresentadas nos meios oficiais colombianos são bastante limitadas, restringindo-se à formação acadêmica e a cargos profissionais de destaque de seus membros. Além disso, o acesso ao currículo dos magistrados da Corte não é simples, pois o direito à intimidade dos funcionários públicos assegura que informações pessoais não precisam ser divulgadas.

Passaram pela Corte Suprema nos últimos 25 anos um total de 74 magistrados, um número bastante alto que reflete tanto sua composição, integrada por 23 membros, quanto a instituição de mandatos de oito anos. A ocorrência de renúncias relaciona-se a "motivos de saúde" e aposentadorias, que se concentram, principalmente em 1994, data em que o mandato vitalício foi substituído pelo de oito anos com aposentadoria compulsória aos 65 anos. Com a instituição de um mandato determinado, não houve mais aposentadorias. O único caso destoante éo do magistrado Arturo Solarte Rodríguez, cuja renúncia em 2003 se deu pela demora em preencher uma vacância na Corte devido a discordâncias e conflitos entre os juízes.

Sobre o perfil dos ministros, percebemos que apenas um pequeno número tem título de doutorado, sendo todos no exterior - na França e na Espanha. O título de especialização é o mais presente, 27 casos, sendo que a maioria dos ministros apresenta mais de um. A formação de graduação em direito apresenta grande diversificação, mas, majoritariamente, se concentra na Universidad Externado de Colômbia. Mais da metade dos integrantes também tem atividade acadêmica. A inserção política é insignificante, apenas um caso na amostra. A grande maioria, 53 casos, tem sua carreira baseada na magistratura. A participação em associações ocorreu em 17 casos; apenas quatro se tratavam de associações corporativas.

\section{As Elites Judiciais no Jogo Político: O Caso da Venezuela}

Gabriel Negretto e Mark Ungar (2007) assinalam que, apesar da autoridade do governo central venezuelano estar praticamente consolidada desde o início do século XX, apenas na década de 1940 é que houve a tentativa de uma organização definitiva do Poder Judicial federal. 
Contudo, tanto o padrão de baixo grau de compromisso dos partidos do país quanto a disseminada desorganização e corrupção dentro do próprio Poder Judiciário impediram a coordenação nesse sentido.

Por meio do regime democrático instaurado em 1958, um sistema onde predominou a conciliação de elites, a Venezuela conheceu um período de estabilidade política. Porém, a judicatura, assim como outros espaços institucionais, converteu-se em área de repartição burocrática dos partidos (Rey, 1991). A criação, em 1968, do Consejo de la Judicatura, responsável pela nomeação e disciplina dos juízes de primeira e segunda instância e pela administração do sistema, não melhorou esse quadro. OConsejo foi rapidamente instrumentalizado pelos partidos políticos que chegaram a um acordo para repartirem os cargos judiciais de modo que as designações de juízes - em todas as esferas - tivessem caráter estritamente partidário (Peréz-Perdomo, 2006). Mesmo com a criação da Ley de Carrera Judicial, em 1980, que introduziu critérios objetivos e meritocráticos para a seleção dos juízes por meio de concursos, o Conselho não seguiu as normas formais. Deixou de realizar os concursos e contribuiu para a consolidação da prática de designar juízes suplentes ou provisórios (Peréz-Perdomo, 2004). No caso da Corte Suprema de Justicia, houve a nomeação de ministros por ambas as câmaras do Congresso para períodos de nove anos.

A eleição de Hugo Chávez em 1999 não alterou esse quadro, apenas afirmou a precária situação judicial. Embora os marcos institucionais tenham evoluído para uma maior profissionalização da seleção dos juízes, os novos procedimentos não foram consolidados. Por exemplo, a Constituição de 1999 estipulou que o ingresso na carreira deveria ocorrer pelos Juzgados de Municipio - menor categoria do ramo - por meio de concurso público que incluísse um programa de formação inicial organizado pela Escuela Nacional de la Magistratura. No entanto, desde 2002, não foram realizados novos concursos, de modo que as designações realizadas ocorreram sem nenhum tipo de controle constitucional (Pérez-Perdomo, 2011).

A Comissão Judicial do Tribunal Supremo de Justiça - amparada por um permanente estado de urgência - dirige esse processo nomeando juízes em regime provisional, passíveis, portanto, de destituição arbitrária. Por causa disso, muitos informes de organizações nacionais e internacionais (El-Hage e Chajtur, 2012; Aequitas, 2011; IBA, 2011; CIDH, 2009) apontam que a independência judicial na Venezuela tem 
sido sistematicamente desrespeitada. Porém, como mencionamos anteriormente, o descumprimento das normas de recrutamento judicial constitui um padrão histórico na Venezuela. Como lembra Gretchen Helmke (2015), antes da eleição de Chávez, o Judiciário já era amplamente reconhecido como uma das instituições mais corruptas e ineficientes do país ${ }^{22}$.

Com a ascensão de Chávez, a Suprema Corte foi substituída pelo Tribunal Supremo de Justicia formado por 32 magistrados. Seus membros passaram a ser eleitos por dois terços da Asamblea Nacional, a partir de lista proposta pelo Poder Ciudadano (composto pela Defensoría del Pueblo, pelo Ministerio Público e pela Controladoria General de la República), para mandatos de 12 anos. A seleção se inicia na Asamblea com a proposição de candidatos, por iniciativa própria ou por organizações vinculadas à atividade jurídica. Após consulta à comunidade, é efetuada uma pré-seleção apresentada ao Poder Ciudadano. Este realiza uma segunda seleção para então apresentar uma lista de candidatos à Asamblea Nacional que fará a seleção definitiva.

Os dados sobre os ministros do Tribunal Supremo de Justicia de Venezuela são bastante restritos. O site do Tribunal publica apenas os currículos de seus 32 magistrados atuais e de poucos ex-magistrados - principalmente membros da extinta Corte Suprema - tornando extremamente difícil a coleta de informações sobre sua composição. Além disso, não há informações oficiais sobre os magistrados nomeados após a Constituição que deixaram o cargo antes do fim de seus mandatos por desavenças com o governo. Nos currículos apresentados, destaca-se o engajamento político dos magistrados: muitos disputaram cargos legislativos ou participaram de governos municipais ou estaduais como assessores.

A maior parte dos ministros é formada na Universidad Central de Venezuela e na Universidad de Santa María, instituições tradicionais. Também destacamos que o Tribunal da Venezuela é onde há maior frequência de integrantes que passaram por postos políticos, seja mandatos representativos ou cargos no Poder Executivo, corroborando a tendência de maior imbricação da Corte com o espaço político. Esse fator pode ser contrastado com a tendência declinante que o Brasil e a Argentina vêm apresentando desde o início do século XIX. Portanto, a maioria dos juízes mobiliza fatores de legitimação externos à carreira da magistratura. 


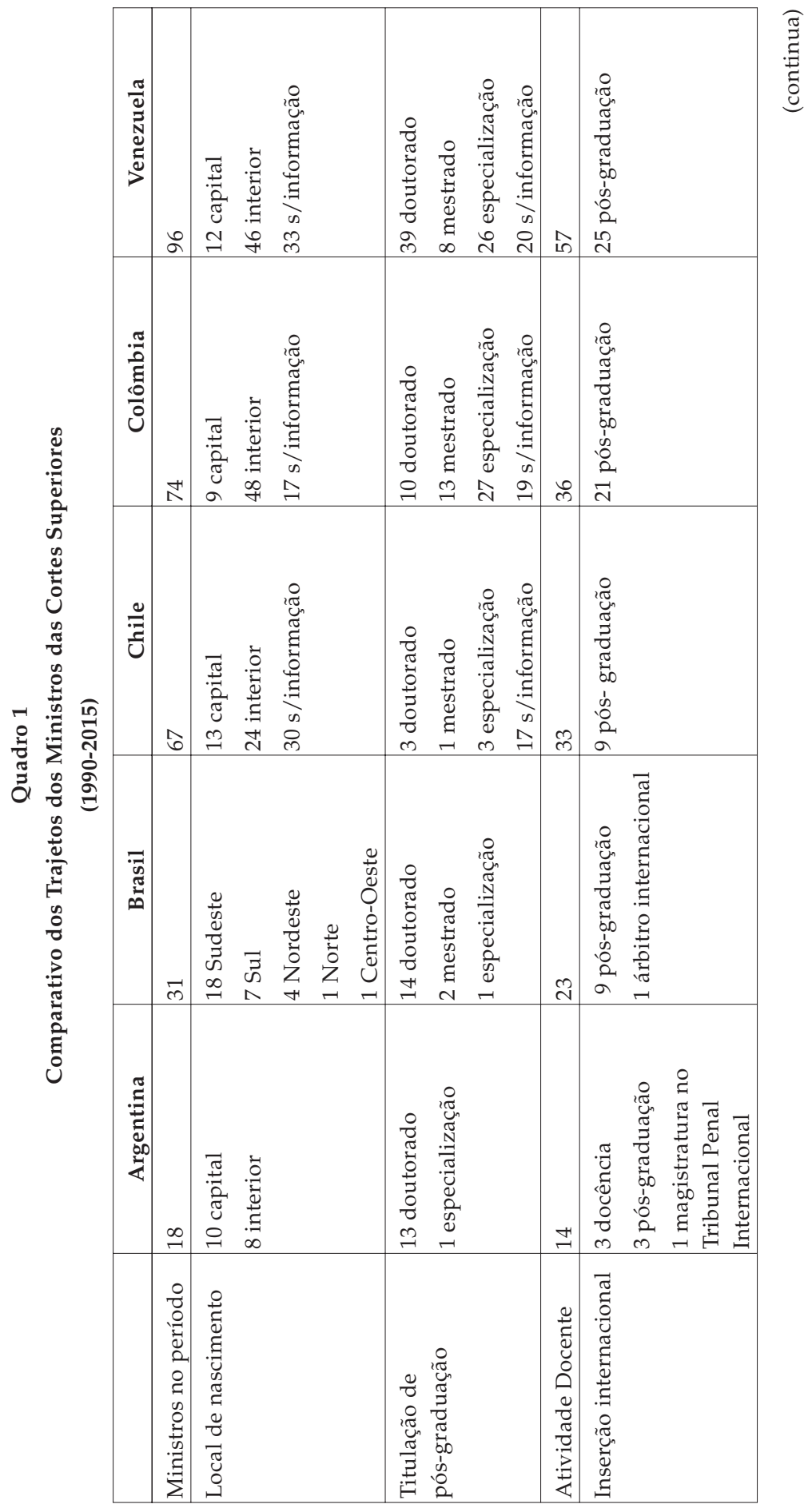

922 DADOS - Revista de Ciências Sociais, Rio de Janeiro, vol. 60, no 4, 2017 
A Construção da Autonomia Política do Judiciário na América Latina

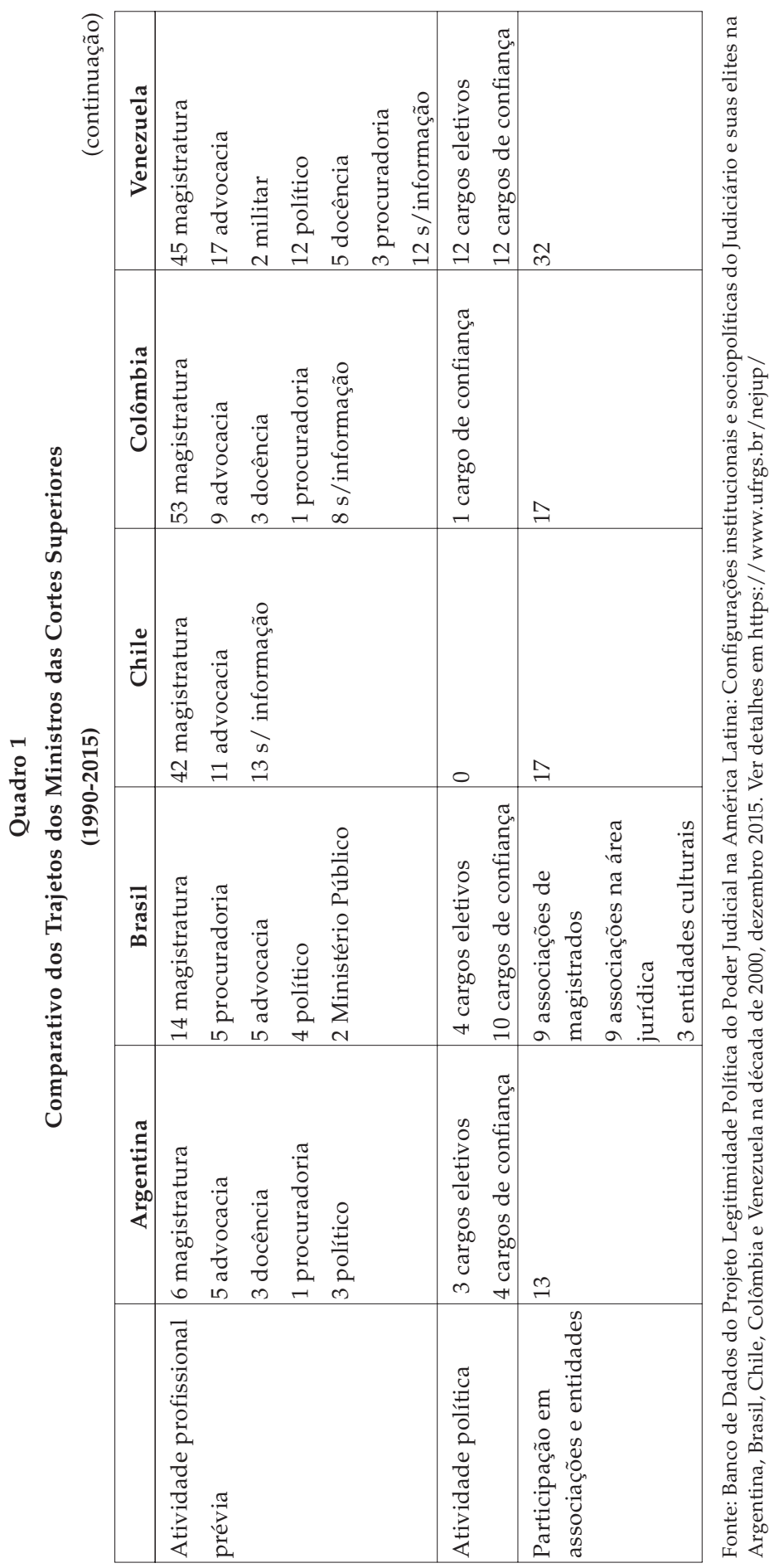

DADOS - Revista de Ciências Sociais, Rio de Janeiro, vol. 60, nํㅜ 4, 2017 


\section{CONSIDERAÇÕES FINAIS}

Os dados comparativos dos percursos dos ministros das Cortes Superiores dos cinco países sob análise trazem indicações que permitem distinguir tanto elementos gerais que caracterizam a elite jurídica quanto dados que se relacionam especificamente às trajetórias de construção da autonomia política e dos mecanismos de recrutamento específicos de cada país. Em um primeiro eixo, pode-se incluir as semelhanças nos percursos dos ministros relacionadas à posse de títulos de pós-graduação, atividade docente e baixa inserção internacional, seja na forma de atividades profissionais ou acadêmicas. Tais elementos independem do grau de autonomia política das Cortes e, no caso da docência e dos títulos de pós-graduação, relacionam-se também com a importância da produção das doutrinas jurídicas e a fraca autonomização das faculdades de direito em relação ao universo das práticas jurídicas, típicas do caso latino-americano (ver Engelmann, 2006 e Dezalay e Garth, 2001).

A baixa inserção internacional dos membros da Corte está em contraste com outros segmentos da elite burocrática em países latino-americanos, como os economistas (ver Dezalay e Garth, 2001). Também podese relacionar esse indicador com a dificuldade de penetração de modelos de reforma do Judiciário ancorados na economia institucional (ver Engelmann, 2015). Ou seja, predomina a reprodução de tradições jurídicas que remontam à colonização espanhola, além do grau de conservadorismo doutrinário que predomina entre os ocupantes de cargos nas cúpulas judiciais.

Quanto ao perfil de atividade profissional prévia ao ingresso na Corte, predomina a origem na magistratura. Nos casos de Brasil e Argentina, há maior frequência de membros oriundos de outras profissões jurídicas. Destacamos, nesse quesito, também os casos da Colômbia e do Chile, onde as Cortes espelham o modelo de "cooptação" na hierarquização do Poder Judiciário, contribuindo para maior autonomia e endogeneização no recrutamento de seus membros. $\mathrm{O}$ caso venezuelano, mesmo se destacando por um padrão histórico de menor autonomia do Poder Judicial, também teve quase metade de seus ministros recrutados da magistratura, evidenciando a força dessa corporação.

No que concerne às atividades políticas, Argentina e Venezuela aparecem como os países cujos ministros da Corte apresentam maior passagem por cargos eletivos contrastando com os modelos de recrutamen- 
to mais corporativo da Colômbia e do Chile. Se compararmos esses indicadores com estudos sobre as elites judiciais que incidem sobre períodos anteriores (ver Dezalay e Garth, 2001), podemos afirmar que há uma tendência, nas últimas duas décadas, de diminuição de ministros que tenham exercido mandatos eletivos. Essa direção atinge mesmo Cortes menos autônomas como as de Argentina e Venezuela que, na última década, introduziram mecanismos institucionais voltados para o distanciamento dos ministros em relação à política representativa. Entretanto, esse indicativo deve ser lido com cuidado, pois resta evidenciar as outras bases de construção de capital político que permitem a ascensão à condição de ministros. Nesse sentido, é importante, entre outros elementos, aprofundar estudos sobre os cargos de poder exercidos no âmbito de tribunais intermediários, sobretudo nos casos dos modelos mais corporativos, assim como as funções de liderança associativa ou porta-voz político da magistratura.

A participação associativa é bastante frequente no caso dos ministros. Mesmo com as limitações das fontes, os dados obtidos nessa dimensão evidenciam uma ocorrência significativa nos percursos dos ministros, com destaque para os casos argentino e brasileiro. O caso argentino destaca-se nesse quesito com um grande pluralismo de associações de magistrados, incluindo uma associação de mulheres magistradas. Em termos gerais, o associativismo corporativo destaca-se no período pós-redemocratização, sendo que em países como o Brasil as associações corporativas de magistrados assumem papel relevante nas articulações que envolvem a indicação de ministros e membros de Conselhos de magistrados (ver Engelman, 2012).

Analisando-se em conjunto os dados dos percursos dos ministros entre 1990 e 2015 e os dados macro-históricos das relações entre o Poder Judiciário e o espaço político, podemos agrupar casos que possuem sentidos próximos nas trajetórias de interação das elites políticas com as judiciais. Essa comparação traz elementos que permitem uma compreensão mais abrangente da dinâmica de construção das relações entre as Cortes superiores e o espaço político na América Latina. Vinculadas a diferentes configurações sócio-históricas e sociopolíticas, essas trajetórias condicionam as modalidades de protagonismo político do Judiciário nos regimes democráticos dos últimos vinte e cinco anos nos países analisados. Nesse sentido, podemos identificar dois caminhos principais de relação entre o poder judicial e o espaço político nos casos estudados. 
No primeiro grupo encontram-se a Argentina e a Venezuela, que apresentam Judiciários com um padrão histórico de baixo grau de autonomia, maior instabilidade institucional e aparelhamento pelos partidos políticos. Tal configuração dificultou a afirmação de um Poder Judiciário independente politicamente e autônomo em sua gestão e recrutamento, o que repercute obviamente na sua atividade jurisdicional. Entretanto, em ambos os casos foram introduzidas, nas últimas décadas, estruturas institucionais voltadas para mecanismos de recrutamento e organização das Cortes que induzem maior autonomia política. Para a Venezuela, a literatura e os dados dos percursos dos ministros das ultimas décadas indicam maior dificuldade de consolidação desses mecanismos, tendo predominado decretos e nomeações de magistrados em regime de exceção. No caso argentino, porém, a tendência à consolidação da autonomia do Poder Judiciário e da Corte Suprema tem sido mais evidente, incluindo casos, na última década, de confronto aberto da Suprema Corte com a vontade do Executivo.

O segundo grupo é formado por Brasil, Chile e Colômbia, nesses casos há uma trajetória histórica onde predomina maior autonomia das Cortes. Os Judiciários chileno e colombiano são considerados os mais independentes da América do Sul, o que pode ser explicado por seus modelos de recrutamento e hierarquização baseados na cooptação. Contudo, esse padrão gerou uma elite judicial autocentrada e alheia às transformações do país, tendência atenuada no caso da Colômbia em que a violenta conjuntura política dos últimos vinte anos tornou o Judiciário mais ativo. O Brasil -apesar de compartilhar o mesmo modelo de recrutamento judicial da Argentina - é um caso típico de grande protagonismo político. A maior estabilidade institucional do país e a preocupação das elites políticas com a legitimação jurídica possibilitou o desenvolvimento de um Judiciário mais autônomo. $\mathrm{O}$ ativismo judicial no Brasil se acentuou ao longo da década de 1990. Pode-se destacar uma significativa ampliação de demandas coletivas pela efetivação de direitos previstos na Constituição de 1988, o arbitramento de disputas entre Legislativo e Executivo e, mais recentemente, o ativismo punitivo presente no "combate a corrupção" (ver Engelmann, 2016).

Os contornos da presença do Judiciário na cena política latino-americana estão longe de estar completamente definidos, tanto nos casos em que a autonomia parece favorecer um hipercorporativismo que restringe a ação de respostas mais efetivas a demandas coletivas quanto 
nos casos em que os regimes democráticos vêm favorecendo uma hiperjudicialização de matérias políticas. Nesses termos, a atenção para padrões históricos de interação das elites judiciais com as elites políticas pode ser um caminho importante para a compreensão das ambivalências da intervenção judicial nas recentes conjunturas políticas instáveis que perpassam a democracia na América Latina. Em alguns casos, uma tendência que cruza os dois eixos, o fortalecimento do corporativismo da magistratura e o crescente protagonismo político, apresenta um fenômeno que ainda está para ser desvendado e que pode trazer uma reconfiguração importante da representação política.

(Recebido em 18/7/2016)

(Reapresentado em 16/1/2017)

(Aprovado em 5/6/2017) 


\section{NOTAS}

1. Para maior detalhamento dos estudos que discutem a noção de "judicialização da política" com base nos regimes democráticos latino-americanos, ver Arantes (1997); Koerner e Maciel (2002); Uprimny (2007); Glopen, Gargarella e Skaar (2005); Gargarella, Domingo e Roux (2006); Sieder, Schjolden e Angell (2006); Taylor (2008); Carvalho (2007); Angel (2009); Couso et al. (2010) e Kapiszewski (2012).

2. São exemplos desse conjunto: Negrettto (1997); Squella (2007); Almeida (2014); Basabe (2013); Engelmann (2012); Engelmann; Penna (2014); Friedman, Perdomo e Fix-Fierro (2003); Dezalay e Garth (2002); Dezalay e Garth (2003); Burgos (2003); Skaar (2011); Magalhães e Carvalho (2014).

3. Para estudos sobre reformas judiciais, ver Acuña e Alonso (2003); De Burca, Kilpatrick e Scott (2013) Finkel (2008); Skaar (2003); Souza (2007).

4. Héctor José Tanzi (2008) ressalta, porém, que no período inicial da Corte é difícil enquadrar sua atuação em determinada escola filosófica. Apesar de sua estrutura institucional sustentar o dinamismo norte-americano, a mentalidade dos juízes ainda carregava a tradição formalista espanhola.

5. As nomeações, tanto da Suprema Corte quanto dos tribunais inferiores, eram de prerrogativa do Executivo, com consenso de uma maioria simples do Senado.

6. Gretchen Helmke (2005) mostra que, entre 1862 e 1946, passaram pela Suprema Corte 35 ministros, que serviram, aproximadamente, por onze anos. Entre 1947 e 1999, com a nova política de destituição, porém, esse número subiu para 57 e o tempo médio de atuação caiu para menos de cinco anos.

7. Inicialmente, Alfonsín ofereceu uma das vacâncias ao candidato peronista que havia perdido as eleições para ele, mas frente a sua negativa, o então presidente formou uma Corte composta por dois juízes ligados ao seu partido (a União Cívica Radical), um advogado peronista, um advogado socialista e um jurista independente.

8. Marcos Novaro (2003) pontua que, apesar da nova formação não ter sido totalmente submissa, nos principais casos sob sua égide posicionava-se a favor do governo atribuindo legalidade às decisões governamentais.

9. Esse maior protagonismo incitou alguns embates com o governo de Cristina Kirchner (2007-2015) que frequentemente criticou o Judiciário por formar um "partido judicial".

10. Nomeado por Raúl Alfonsín, o juiz Carlos Fayt tinha 96 anos em 2014, portanto já havia ultrapassado a idade de 75 anos para aposentadoria da Corte instituída pela reforma constitucional de 1994. No entanto, sua continuidade foi assegurada por uma sentença de 1999. A decisão estabeleceu que aqueles juízes nomeados antes da reforma estariam isentos da aposentadoria, ou seja, seus mandatos permaneceriam vitalícios. Fayat permaneceu na Corte até setembro de 2015 e veio a falecer em 22 de novembro de 2016.

11. O Pacto de Olivos corresponde a uma série de acordos realizados entre o ex-presidente Raúl Alfonsín (UCR) e o então presidente Carlos Menem (PJ) para assegurar o apoio dos radicalistas à reforma constitucional de 1994 pretendida pelos justicialistas. 
12. Como aponta Lisa Hilbink (2007), apesar de este ser um fato singular em um continente marcado pela instabilidade, isso mostra que o Judiciário do país não se caracteriza apenas como estável, mas, principalmente, como uma instituição indiferente às mudanças sociopolíticas que ocorrem em sua volta e, consequentemente, rígida e pouco adaptável.

13. Yves Dezalay e Bryant Garth (2002) afirmam que, inicialmente, as Cortes eram formadas pelas tradicionais elites oligárquicas, mas que, devido ao papel secundário do Judiciário, a partir do século XX, esse laço começa a ser cortado de modo que no final da década de 1960 poucos membros das famílias oligárquicas encontravam-se no poder judicial.

14. Outros modelos de cooptação judicial já haviam sido implementados no país durante o século XIX, de modo que a Suprema Corte sempre manteve algum grau de poder nas nomeações do Judiciário. A singularidade do modelo instituído, então, repousa na centralidade da Suprema Corte no recrutamento e na formação dos magistrados dentro da ideia de separar a magistratura do espaço político.

15. Apesar de não ter havido destituições durante a ditadura de Rojas, todos os magistrados da Corte renunciaram durante seu governo. Segundo Mario Cajas Sarria (2013), embora a Corte tenha saudado a chegada ao poder de Rojas, em pouco menos de um ano de governo instaurou-se uma crise entre os Poderes quando um juiz penal absolveu um cidadão frente à acusação de terrorismo por parte do Exército. Com isso, o general acusou o Judiciário de estar politizado, ter motivações partidárias e não estar à altura das mudanças de que o país precisava.

16. A Frente Nacional foi um acordo legitimado por um referendo constitucional, que instaurou a rotatividade na presidência entre os Liberais e Conservadores (por quatro mandatos presidenciais) e estabeleceu a divisão igualitária do poder político e burocrático entre eles (Pécaut, 2010; Bushnell, 1993).

17. Entre 1949 e 1991, a Colômbia acumulou mais de 30 anos sob estado de sítio sendo que, a partir de 1965, os militares tinham permissão para investigar e punir civis. No final da década de 1970, cerca de 30\% dos crimes previstos no Código Penal estavam sob a competência dos tribunais marciais (Uprimny, 2004).

18. Estima-se que, entre 1979 e 1991, 290 juízes e funcionários judiciais foram assassinados, tanto por guerrilheiros quanto por traficantes e paramilitares (Uprimny, Rodriguez e Villegas, 2003).

19. Apesar de a Colômbia não ter vivido uma ditadura militar no período em que elas se espalharam pelo continente, o regime pactuado em torno da Frente Nacional estava longe de se configurar como abertamente democrático. Portanto, o país acompanhou seus vizinhos em suas transições democráticas, sendo a Constituição de 1991 um reflexo desse processo.

20. Órgão encarregado de gerenciar o aparato judicial, o Conselho Superior da Judicatura é autônomo patrimonial, orçamental, financeira e administrativamente.

21. A Corte Constitucional foi alvo de diversas críticas por introduzir o Legislativo e o Executivo no processo de recrutamento dos juízes. Todavia, essa politização foi defendida para evitar o controle de um corpo elitista desconectado da realidade social e política do país, como acontecia nas cortes tradicionais. Mesmo com o temor inicial, a Corte Constitucional tem mostrado independência política e interpretações progressistas da Constituição (Uprimny, 2004). 
22. De acordo com Helmke (2015), na década de 1990 um sucesso de vendas no país foi o livro Cuánto Vale un Juez? que descrevia a participação de grandes escritórios de advocacia em redes informais que permitiam que seus clientes comprassem decisões favoráveis. O autor do livro acabou preso.

\section{REFERÊNCIAS BIBLIOGRÁFICAS}

ACUÑA, Carlos; ALONSO, Gabriela. (2003), “La Reforma Judicial en América Latina: Un Estudio Político-institucional de las Reformas Judiciales en Argentina, Brasil, Chile y México". Working Paper, no 28, Universidad de San Andrés, pp. 1-49.

AEQUITAS. (2011), Informe sobre la Independência del Poder Judicial para el Examen Periódico Universal Venezuela, 12a sesión, Disponível em http://lib.ohchr.org/ HRBodies/UPR/Documents/session12/VE/AEQUITAS-spa.pdf

ALMEIDA, Frederico. (2010), A Nobreza Togada: As Elites Jurídicas e a Política da Justiça no Brasil. São Paulo. Tese (Doutorado em Ciência Política), Universidade de São Paulo, São Paulo.

. (2014), “As Elites da Justiça: Instituições, Profissões e Poder na Política da Justiça Brasileira”. Revista de Sociologia e Política, vol. 22, no 52, pp. 77-95.

ARANTES, Rogério. (1997), Judiciário e Política no Brasil. São Paulo, Editora Sumaré.

BADIE, Bertrand; HERMET, Guy. (1990), Política Comparada. México, FCE.

BANCAUD, Alain. (1993), La Haute Magistrature Judiciaire entre Politique et Sacerdoce ou le Culte des Vertus Moyennes. Paris, Librairie Générale de Droit et de Jurisprudence.

BARBOSA, Cláudia Maria. (2003), "Algunos Aspectos de la Independência del Poder Judicial en Brasil”, in G. Burgos (ed.), Independência Judicial en América Latina. De Quien? Para Que? Como? Bogotá, Publicaciones ILSA, pp. 417-417.

BASABE, Santiago. (2013), “Explicando la Corrupción Judicial en las Cortes Intermedias e Inferiores de Chile, Perú y Ecuador”. Perfiles Latino-americanos, no 42, pp. 79-108.

BOURDIEU, Pierre. (1986), "La Force du Droit". Actes de la Recherche en Sciences Sociales, vol. 64 , no 1, pp. 3-19.

BURGOS, German (ed.). (2003), Independência Judicial en América Latina. De Quien? Para Que? Como? Bogotá, Publicaciones ILSA.

BUSHNELL, David. (1983), The Making of Modern Colombia: A Nation in Spite of Itself. California, University of California Press.

CARVALHO, Ernani. (2007), “Revisão Judicial e Judicialização da Política no Direito Ocidental: Aspectos Relevantes de sua Gênese e Desenvolvimento". Revista de Sociologia e Política, no 28, pp. 161-179. 
CIDH (Comissão Interamericana de Direitos Humanos). (2009), Informe Democracia y Derechos Humanos en Venezuela. Disponível em http://www.cidh.oas.org/ countryrep/Venezuela2009sp/VE09.indice.sp.htm.

COUSO, Javier; HUNEEUS, Alexandra; SIEDER, Rachel. (2010), Cultures of Legality. Judicialization and Political Activism in Latin America. Cambridge, Cambridge University Press.

CUMPLIDO, Francisco; FRUHLING, Hugo. (1980), "Problemas Jurídico-Políticos del Transito Hacia la Democracia. Chile: 1924-1932". Estudios Sociales, vol. 21, pp.71-113.

DA ROS, Luciano. (2012), “Juízes profissionais? Padrões de Carreira dos Integrantes das Supremas Cortes de Brasil (1829-2008) e Estados Unidos (1789-2008)". Revista de Sociologia e Política, vol. 21, no 41, pp. 149-169.

DE BURCA, Grainne; KILPATRICK, Claire; SCOTT, Joanne. (eds.). (2013), Critical Legal Perspectives on Global Governance: Liber Amicorum David M. Trubek. Oxford, Hart Publishing.

DEL RÍO, Andrés. (2012), “La Corte Suprema de Justicia Argentina y El Orden Conservador: Un Análisis de Trayectorias (1853-1930)". Revista Internacional de História Política e Cultura Jurídica, vol. 4, no1, pp. 132-152.

DEZALAY, Yves; GARTH, Bryant. (2001), “Constructing law out of power: Investing in $\mathrm{Hu}$ man Rights as an Alternative Political Strategy", in A. Sarat; S. Schingold (eds.), Cause Lawyering and the State in a Global Era. Oxford, New York, Oxford University Press, pp. 354-381.

. (2002), The Internationalization of Palace Wars: Lawyers, Economists, and the Contest to Transform Latin American State. Chicago, The University of Chicago Press.

. (2003), “Patrones de Inversión Jurídica Extranjera y de Transformación del Estado en América Latina", in L. Friedman; R. Perdomo; H. Fix-Fierro (orgs.), Culturas Jurídicas Latinas de Europa y América en Tiempos de Globalizacion. México, Unam, pp. 723-747.

ECHEVERRÍA, Andrés. (2011), “El Protagonismo Político del Poder Judicial entre los Años 1965 y 1973". Revista de Derecho, no 36, pp. 619-663.

EL-HAGE, Javier; CHAJTUR, Centa. (2012), Informe sobre el Estado de la Independencia del Poder Judicial en Venezuela. New York, Human Rights Foundation.

ENGELMANN, Fabiano. (2006), Sociologia do Campo Jurídico: Juristas e Usos do Direito. Porto Alegre, Safe.

. (2012), "Globalização e Poder de Estado: Circulação Internacional de Elites e Hierarquias do Campo Jurídico Brasileiro". DADOS - Revista de Ciências Sociais, vol. 55, no 2, pp. 97-125.

. (2016), "Julgar a Política, Condenar a Democracia?" Conjuntura Austral, vol. 7, pp. 9-16.

. (2015), "Sentidos Políticos da Reforma do Judiciário no Brasil / Political Senses of Judicial Reform in Brazil". Revista Direito e Práxis, vol. 6, pp. 395-412.

; PENNA, Luciana. (2014), “Política na Forma da Lei: O Espaço dos Constitucionalistas no Brasil Democrático". Lua Nova, vol. 92, pp. 177-206. 
FERREIRA, Fátima Moura. (2001), “Alguns Contornos da Configuração do Campo Jurídico. A Elite Judicial do Supremo Tribunal de Justiça (1833-1851)”. Penélope, no24, pp. 121-146.

FINKEL, Jodi. (2008), Judicial Reform as Political Insurance: Argentina, Peru and Mexico in the 1990s. Notre Dame, University of Notre Dame Press.

FRIEDMAN, Lawrence; PERDOMO, Rogelio; FIX-FIERRO, Hector (orgs.). (2003), Culturas Jurídicas Latinas de Europa y América en Tiempos de Globalización. México, Unam.

FRUHLING, Hugo. (1980), "Poder Judicial y Política en Chile". Contribuciones FLACSO, no 03, pp. 4-44.

GALVIS, Sebastian. (2009), “La Corte Constitucional: Entre la Independencia Judicial y la Captura Política", in M. Villegas; J. Rebolledo (eds.), Mayorías sin Democracia. Desequilibrio de Poderes y Estado de Derecho en Colombia, 2002-2009. Bogotá, De Justicia, pp. 85-146.

GARGARELLA, Roberto; DOMINGO, Pilar; ROUX, Theunis (eds.). (2006), Courts and Social Transformation in New Democracies: An Institutional Voice for the Poor? London, Ashgate.

GLOPEN, Siri; GARGARELLA, Roberto; SKAAR, Elin. (2005), Democratization and the Judiciary: The Accountability Function of Courts in New Democracies. London, Frank Cass.

GUEVARA, Carolina. (2011), “Independencia Judicial: El Caso de la Corte Suprema de Justicia Colombiana”. Revista de Derecho, no 35, pp. 145-179.

HELMKE, Gretchen. (2005), Courts under Constraints: Judges, Generals, and Presidents in Argentina. New York, Cambridge University Press.

. (2015), Institutions on the Edge: Inter-Branch Crises in Latin America. New York, Cambridge University Press.

HERRERO, Álvaro. (2012), “Avances en la Selección de Jueces en Argentina: Un Ejemplo de Colaboración entre el Estado y la Sociedad Civil. Revista Aportes DPLF, vol. 5, no 17, pp. 10-12.

HILBINK, Lisa. (2003), "An Exception to Chilean Exceptionalism? The Historical Role of Chile's Judiciary", in S. Eckstein; T. Wickham-Crowley (orgs.), What Justice? Whose Justice? Fighting for Fairness in Latin America. Berkeley, University of California Press, pp. 64-97.

. (2007), Judges beyond Politics in Democracy and Dictatorship: Lessons from Chile. New York, Cambridge University Press.

. (2008), "Agents of Anti-Politics: Courts in Pinochet's Chile", in T. Ginsburg; T. Moustafa (orgs.), Rule by Law: The Politics of Courts in Authoritarian Regimes. Cambridge, Cambridge University Press, pp. 102-131.

IBA (International Bar Association). (2011), “La Desconfianza en la Justicia: El caso Afiuni y la independencia de la Judicatura Venezolana". Informe de la International Bar Association. Disponível em http://www.ibanet.org/Document/Default. aspx?DocumentUid=0E0DC15A-4F39-4EE6-81F5-F36A60D90231

KAPISZEWSKI, Diana. (2012), High Courts and Economic Governance in Argentina and Brazil. New York, Cambridge University Press. 
KOERNER, Andrei. (1998), Judiciário e Cidadania na Constituição da República Brasileira (1841-1920). Curitiba, Ed Juruá.

; MACIEL, Débora Alves. (2002), “Sentidos da Judicialização da Política: Duas Análises". Lua Nova, no 57, pp. 113-133.

LIZANA, Eduardo. (2001), “La Constitución Monárquica del Poder Judicial”. Revista de Derecho de la Universidad Católica de Valparaíso, no 22, pp. 193-207.

MAGALHÃES, Rebecca; CARVALHO, Ernani. (2014), “Há um Desenho Institucional Favorável à Independência Judiciária? Um Panorama da Constituições Vigentes na América Latina". Revista Debates, vol. 8, no 3, pp. 119-140.

MARTíN, Lucas. (2011), “Giro Judicial y Legitimidad Pública en la Política Argentina”, in I. Cheresky (ed.), Ciudadanía y Legitimidad Democrática en América Latina. Buenos Aires, Prometeu, pp. 363-393.

MENAJOVSKY, Laura. (2015), “La Construcción de Legitimidad de la Corte Suprema de Justicia en Argentina". Documentos de Coyuntura del Área de Política (IDH-UNGS), no 3, pp. 3-12.

MONARDES, Alvaro F. (2005). “Gobierno Judicial: El Caso Chileno la Reforma Olvidada". Revista de Estudios de la Justicia, no 6. pp 9-16.

MORENO, Diego Y. (2004). Panorama de las Reformas del Estado y de la Administración Pública. Bogotá, Centro Editorial Universidad del Rosario.

NAGLE, Luz. (1995), "Evolution of the Colombian Judiciary and the Constitutional Court". Indiana International and Comparative Law Review, vol. 6, no 1, pp. 59-90.

NEGRETTO, Gabriel; UNGAR, Mark. (1997), “Independencia del Poder Judicial y Estado de Derecho en America Latina: Los Casos de Argentina y Venezuela". Revista Política y Gobierno, vol. IV, no 1, pp. 81-114.

NEMOGA, Gabriel. (1995), “Crisis Judicial: Enfoques Diferentes y Elementos Constantes". Revista Pensamiento Jurídico, no 4, pp. 107-130.

NOVARO, Marcos. (2003), "Presidentes, Equilíbrios Institucionales y Coaliciones de Gobierno en Argentina (1989-2000)", in J. Lanzaro (org.), Tipos de Presidencialismo y Coaliciones Políticas en América Latina. Buenos Aires, CLACSO, pp. 51-100.

; PALERMO, Vicente. (2007), A Ditadura Militar Argentina 1976-1963: Do Golpe de Estado à Restauração Democrática. São Paulo, Ed. USP.

PÉCAUT, Daniel. (2010), As FARC: Uma Guerrilha sem Fins? São Paulo, Paz e Terra.

PÉREZ PERDOMO, Rogelio. (2004), “Reforma Judicial, Estado de Derecho y Revolución en Venezuela", in L. Pasara. (org.), En Busqueda de una Justicia Distinta. Experiencias de Reforma en América Latina. Lima, Consorcio Justicia Viva, pp. 335-374.

(2006), "La Reforma Judicial en la Venezuela Revolucionaria", in P. De Shazo; J. Vargas (eds.), Judicial Reform in Latin America. An Assessment for Policy Makers. Santiago, CEJA.

. (2011), Justicias e Injusticias en Venezuela: Estudios de Historia Social del Derecho. Caracas, Academia Nacional de la Historia.

REY, Juan. (1991), “La Democracia Venezolana y la Crisis del Sistema Político de Conciliación”. Revista de Estudios Políticos, no 74, pp. 533-578. 


\section{Fabiano Engelmann e Júlia Veiga Vieira Mâncio Bandeira}

SABSAY, Daniel. (2004), “El Juicio Político a la Corte Suprema en la República Argentina". Anuario Iberoamericano de Justicia Constitucional, no 8, pp. 493-519.

SAMPER, Andrés. (2012), “La Historia de la Rama Judicial en Colombia”. Criterio Jurídico Garantista, vol. 3, no 6, pp. 154-187.

SARRIA, Mario Cajas. (2008), El Control Judicial a la Reforma Constitucional. Colombia, 1910-2007. Cali, Universidad Icesi.

. (2013), “Alfonso López Pumarejo y la Última Corte Suprema de Justicia de la Hegemonía Conservadora, 1934-1935”. Revista de Derecho, no 40, pp. 98-135.

SIEDER, Rachel; SCHJOLDEN, Line; ANGELL, Alan (eds.). (2006), The Judicialization of Politics in Latin America. New York, Palgrave.

SKAAR, Elin. (2003), “Un Análisis de las Reformas Judiciales de Argentina, Chile y Uruguay". América Latina Hoy, no 34, pp. 147-186.

SKAAR, Elin. (2011), Judicial Independence and Human Rights in Latin America: Violations, Politics and Prosecution. New York, Palgrave Macmillan.

SOUSA, Mariana. (2007), “Breve Panorama de la Reforma Judicial en América Latina: Objetivos, Desafíos y Resultados", in E. Lora (ed.), El Estado de las Reformas del Estado en América Latina. Washington, BID, pp. 99-137.

SQUELLA, Agustín. (2007), “Independencia Interna del Poder Judicial: Ante Quiénes, en Qué y para Qué Tenemos Jueces Independientes", in F. Atria; J. Couso (eds.), La Judicatura como Organización. Santiago, Expansiva, pp. 99-32.

TANZI, Héctor José. (2008), “Historia Ideológica de la Corte Suprema 1903-1930". Iushistoria, no 05 , pp. 147-244.

TAYLOR, Matthew. (2008), Judging Policy: Courts and Policy Reform in Democratic Brazil. Stanford, Stanford University.

UPRIMNY, Rodrigo. (2004), "The Constitutional Court and Control of Presidential Extraordinary Powers in Colombia", in S. Gloppen; R. Gargarella; E. Skaar (eds.), Democratization and the Judiciary: The Accountability Function of Courts in New Democracies. Portland, Frank Cass Publishers, pp. 33-49.

(2007), “A Judicialização da Política na Colômbia: Casos, Potencialidades e Riscos". Sur, Revista Internacional de Direitos Humanos, vol. 4, no 6, pp. 52-69.

; RODRIGUEZ, César; VILLEGAS, Maurício. (2003), “Entre el Protagonismo y la Rutina: Análisis Sociojurídico de la Justicia en Colombia", in H. Fix-Fierro; L. Friedman; J. P. Perdomo (eds.), Culturas Jurídicas Latinas de Europa y América en Tiempos de Globalización. México, Universidad Nacional Autónoma de México, Instituto de Investigaciones Jurídicas, pp. 231-304.

VILLEGAS, Mauricio. (2009), “Caracterización del Régimen Político Colombiano (1956-2008)", in M. Villegas; J. Rebolledo (ed.), Mayorías sin Democracia. Desequilibrio de Poderes y Estado de Derecho en Colombia, 2002-2009. Bogotá, De Justicia. 


\section{RESUMO}

A Construção da Autonomia Política do Judiciário na América Latina: Um Estudo Comparado entre Argentina, Brasil, Chile, Colômbia e Venezuela

O artigo traz elementos para a compreensão histórico-política das relações entre as Cortes superiores e o espaço político na América Latina. A análise enfoca os regimes políticos dos últimos vinte e cinco anos na Argentina, Brasil, Chile, Colômbia e Venezuela. O objetivo central é a compreensão dos padrões de recrutamento das cúpulas judiciais e seu grau de autonomia em relação ao espaço político. Os dados são construídos a partir da comparação histórica e dos perfis e trajetos políticos, profissional e intelectual dos componentes das cortes superiores. Os resultados obtidos evidenciam diferentes configurações nos países analisados permitindo opor os cenários nos quais predominam a autonomia corporativa das cortes superiores aos que se caracterizam por maior imbricação entre as cúpulas judiciais e a esfera política.

Palavras-chave: recrutamento de elites; independência judicial; América Latina; política; Judiciário

\section{ABSTRACT \\ The Shaping of The Judiciary's Political Autonomy in Latin America: A Comparative Study Between Argentina, Brazil, Chile, Colombia, and Venezuela}

The following article aims to contribute to a historical-political understanding of relations between the superior courts and the political space in Latin America, with the analysis focusing on political regimes in Argentina, Brazil, Chile, Colombia, and Venezuela over the past 25 years. The main objective is to better understand the recruitment procedures for judiciaries and the extent of their autonomy in terms of the public space. The data is collected by means of a historical comparison and from the political, professional, and intellectual profiles and trajectories of members of the superior courts. The results obtained demonstrate a variety of setups in the countries analyzed, allowing us to contrast scenarios dominated by the superior courts' corporate autonomy from those instead characterized by the courts' greater overlap with the public sphere.

Key words: recruitment of elites; judicial independence; Latin America; politics; Judiciary 
RÉSUMÉ

La Construction de l'autonomie Politique du Pouvoir Judiciaire en Amérique Latine: Une Étude Comparée entre Argentine, Brésil, Chili, Colombie et Venezuela

Cet article fournit des éléments visant à la compréhension historico-politique des rapports entre les cours suprêmes et l'espace politique latino-américain. Notre analyse s'est concentrée sur les régimes politiques de ces vingt-cinq dernières années en Argentine, au Brésil, au Chili, en Colombie et au Venezuela. Il s'agit principalement d'appréhender les normes de recrutement des élites judiciaires et leur degré d'autonomie par rapport à l'espace politique. Nos données ont été élaborées à partir de la comparaison de l'histoire, des profils et des trajectoires politiques, professionnels et intellectuels des magistrats des cours suprêmes. Les résultats obtenus ont mis en évidence des configurations diverses dans les différents pays analysés, ce qui a permis d'opposer les contextes où prédomine l'autonomie corporative des cours suprêmes à ceux qui se caractérisent par une imbrication plus importante entre les sphères judiciaire et politique.

Mots-clés: recrutement des élites; indépendance judiciaire; Amérique Latine; politique; Justice

\section{RESUMEN}

La Construcción de la Autonomía Política del Poder Judicial en América Latina: Un Estudio Comparativo de Argentina, Brasil, Chile, Colombia y Venezuela

El artículo aporta elementos para la comprensión histórico-política de las relaciones entre las Cortes Superiores de Justicia y el espacio político en América Latina. El análisis se centra en los regímenes políticos de los últimos veinticinco años en Argentina, Brasil, Chile, Colombia y Venezuela. El objetivo central es comprender los patrones de reclutamiento de las cúpulas judiciales y su grado de autonomía en relación con el espacio político. Los datos se basan en la comparación histórica y los perfiles y trayectorias políticas, profesionales e intelectuales de los componentes de las Cortes Superiores. Los resultados obtenidos evidencian diferentes configuraciones en los países analizados, lo que permite comparar los escenarios en los que predominan la autonomía corporativa de las Cortes Superiores y aquellos caracterizados por una mayor interrelación entre las cúpulas judiciales y la esfera política.

Palabras clave: reclutamiento de altos cargos; independencia judicial; América Latina; política; poder judicial 